\section{Smithsonian Institution Activities}

The report of the Secretary of the Smithsonian Institution and the financial report of the Executive Committee of the Board of Regents for the year ended June 30, 1941, includes a summary of the year's activities and reports on the United States National Museum, the Bureau of American Ethnology, the International Exchange Service, the National Zoological Park, the Astrophysical Observatory, the Division of Radiation and Organisms and other activities (Washington: Gov. Printing Office. 25 cents). The Smithsonian Institution has already been assigned a number of defence problems. The revision of all solar-constant values collected by the Astrophysical Laboratory from all Smithsonian observing stations from 1923 to the present is nearing completion and publication is.expected to commence in 1942. A promising method has been developed of following the sun's variation by observations limited to the blue-violet region of the spectrum.

The Division of Radiation and Organisms has continued its studies on the relation of radiation to various phases of plant growth, and much information has been acquired on the respiration of etiolated barley seedlings. In addition to improvements in the performance of the spectrograph used in measuring carbon dioxide for very short periods, the spectral effectiveness of radiation for the growth inhibition of the oat mesocotyl has been further studied, as well as those of other species of grasses, and the ultra-violet irradiation of algæ. M. W. Stirling has made further archæological discoveries in southern Mexico in co-operation with the National Geographic Society, and Dr. Frank H. H. Roberts, jun., has completed his sixth and final expedition to the Linden. muir site in northern Colorado, work which has added greatly to our knowledge of Folsom man and the early occupation of America. The work of the International Exchange Service was seriously hampered by world conditions, but scientific and other publications which cannot now be sent are being stored until the end of hostilities.

\section{Meteorology in Art}

Mr. L. C. W. Bonacina's paper on the "Scenic Approach to Meteorology" (Quart. J. Roy. Meteor. Soc., Oct., 1941), his fifth essay on the landscapeimpression of weather, is a valuable contribution to that co-operation between science and art which is so important for the development of human personality. Truth and beauty, long kept in separate compartments of the mind, are now being welded together, a task in which Mr. Bonacina is a diligent and gifted worker. The papers of 1937-38 contain analyses of the paintings of Constable and Turner; that of 1939 carries on the subject to the treatment of landscape-meteorology by men of letters, and those of 1940-41 deal with the pictorial relation of atmosphere and the landscape background as seen by the author. In these descriptions there is a power of expression which enables the reader to share that faculty of observation with which the writer is endowed. Development of the æesthetic appreciation of Nature is especially valuable at the present time. At long last it is beginning to be realized that beauty should take an equal place with truth and goodness in that trinity of enduring values which is needed to fortify the mind during the stress and strain of war.

\section{Rainbow Bridge over the Niagara Falls}

THE approaching completion of the Rainbow Bridge at Niagara Falls, is a happy augury of that closer co-operation between the United States and Canada which has been intensified by the present state of world relations. The bridge was built under the auspices of an international body, the Niagara Falls Bridge Commission, consisting of eight members, four having been appointed by the Governor of New York and four by the Lieutenant-Governor of Ontario. The project has been financed by a bond issue of four million dollars.

The previous bridge at the same place, the correct name of which was the Falls View Bridge, was built in 1895. This was an arch structure which stood until January 27,1938 . On that day an ice jam which had formed in the gorge rose to an unprecedented height, and crushed the end portions of the arch ribs, causing a complete collapse of the bridge. The Falls View Bridge was the property of the International Railway Company, which after its destruction immediately prepared plans for a new structure. Public opinion, however, opposed the construction of another privately owned toll-bridge at this site and as a result the Company did not proceed with the plans for rebuilding. The Niagara River at the Bridge site flows through a gorge approximately $1,250 \mathrm{ft}$. wide and $180 \mathrm{ft}$. deep from the surface of the water to the top of the cliffs. The river is about $830 \mathrm{ft}$. wide and $175 \mathrm{ft}$. deep, and the flow is $25-30$ m.p.h.

\section{Demonstration of the Circulation by Experiment}

IN a recent paper (Isis, 33, $443 ;$ 1941) entitled "The Significance of the Demonstration of the Harveyan Circulation by Experimental Tests" Dr. H. P. Bayon raises the question already put forward by Sarton in 1937 as to why the discovery of the circulation of the blood was completed by an English physician and why its acceptance was delayed until the middle of the seventeenth century. Galen's erroneous doctrine of the to-and-fro movement of the blood which was accepted for so long a period was based on the belief that the anatomical features of the heart, uterus and liver in the dog or pig must also be present in man. According to Dr. Bayon, the delay in the acceptance of Harvey's discovery of the circulation until the middle of the seventeenth century was due to the fact that it was not until then that accurate comparative anatomical observations became available through woodcuts, printed works and dissection. It was by the intelligent use of the experimental method that Harvey was able to test and control his interpretation of clinical observation and comparative anatomy. His investi. gations were completed by the discovery of the capillaries, which formed the missing link between the arteries and veins.

\section{Golf Courses during War-time}

VoL. 6 of the Journal of the Board of Greenkeeping Research, which has just been published, shows that the Research Station at Bingley is adapting itself most successfully to the new problems which are confronting golf clubs owing to the War. Land is being ploughed up on many courses, hay and silage crops are being taken from others and sheep-grazing is widespread. In consequence, the erection of adequate fencing has become a major problem. Trials are 